\title{
STANDARDIZATION OF RECORDS MANAGEMENT SYSTEM IN LOCAL GOVERNMENT UNITS \\ (PHASE 1: Assessment of the Records Management System of Local Government Units)
}

\author{
Ethelmay R, Romero, MBA \\ ethelmayromero@gmail.com \\ Laguna State Polytechnic University, Sta. Cruz, Laguna, 4009, Philippines
}

\begin{abstract}
The study, Assessment of the Records Management System (RMS) of Local Government Units in the Local Government of Laguna, aimed at the assessment of RMS that is being practiced by the province on its Phase 1 . This will become a basis for the Standardization of the Records Management System in the Local Government Units in Laguna.

It dealt with the parameters of RMS as to; (1) IRMS, (2) Record management program, (3) Regulatory Environment (4) Functionality and components of record system, (5) Record management processes and control, (6) ARMA, (7) Filing Methods, (8) Filing Procedures, and (9) Indexing Rules and as being practice currently by the Local Government of Laguna.

The Administrative Professionals of the eight (8) Municipal Government or four (4) Districts of the Province of Laguna were the respondents of the study. From the 160 Administrative professionals in the Municipal Government, a result of "Very Satisfactory" the nine (9) RMS parameters was drawn. This can be inferred that the Province of Laguna strongly agreed on the given parameters and is currently practicing RMS across Municipalities.
\end{abstract}

On the other hand, the seven (7) Municipalities has no significant difference on the RMS practices, except one (1) from the eight (8) having a significant difference on its RMS practices in all Municipalities that were assessed.

This can be inferred that the Province of Laguna has its implementing RMS that is considered to be adhering to the standard measures. Nevertheless, the municipalities in Laguna have uncommon RMS practices which is needed to be standardized as to international standard and as to practice or implementation.

Keywords: RMS; IRMS, ARMA; Administrative Professional; LGU; 


\section{Introduction}

Administration is an integral part of the LGU offices and well respected for the important work that they do. In addition to their salary wages, it also has various benefits from the government they work for.

ISO 15489, the first international standard devoted to records management, provides a comprehensive and practical basis for auditing full and partial records management programs.

The Records Management \& Administrative Assistant organizes and manages the hardcopy documents for the Administrative Division by creating, deleting, retrieving and replacing files. This position reports to and provides administrative support for the Administrative Professionals and staff as designated. It is a visible position and makes some independent decisions within the scope of responsibility; it has some company-wide formal and informal influence.

As a result, the Records Management \& Administrative Assistant must demonstrate quality outcomes and be above censure (i.e., reliable, sincere, discrete, prudent, and honest).

Administrative professionals play a key part in holding a team together and a lot of organizations would fall apart without them. Professionals who hold well-developed administrative skills help to ensure the organization runs efficiently and constitute a crucial factor in the management of projects and growth initiatives.

According to Mosweu T. (2019), records form the backbone of every organization as they are used as evidence of business operations. Citizens can also use them to make informed decisions and hold governments accountable.

Sited by Xiaomi A., Hongyan J. (2011), ISO 15489 has provided best practice guidelines for records management which have many implications to the world.

Stated by Procter J. (2013), the Information Technology (IT) community has a long and often quite turbulent history of standard setting, and given the multiplicity of technological standards required the development process has attracted the interest of a small group of researchers.

Cited by Mutula, S.M. (2015), records management has become a game changer in the records and archives management field. Traditional records and archives management work procedures, work methods, theories and principles have been questioned and new schools of thought, paradigms and philosophies birthed.

Moreover according to research Hughes C. (2016), since the launch of ISO-15489 there have been more opportunities available to records managers to help them align themselves to the strategic direction of their organization, raise their profile and increase awareness of their role.

As per Freda A., (2014), in order to define records management, the concept of "record" needs to be fully explored. A record is defined either in terms of the physical tangible format in which it appears, or in terms of the information it contains.

According to McCue C. (2015), most departments maintain large records management systems (RMS) that contain crime incident data. In most cases, however, these "databases" were not necessarily designed to be analyzed. Rather, these databases were created and are used for case management and general crime counting. As a result, these databases frequently have standard or "canned" queries that facilitate gathering frequently used information or reports; however, these often have limited utility for crime analysis. 
Lewellen M. J. (2015), an authentic record is one that can be proven to be what it purports to be, to have been created or sent by the person purported to have created or sent it, and to have been created or sent at the purported time (ISO 15489.1, 2002, p. 7).

According to Geofrey K. (2013), identified a need to recommend a system for managing records at the Economic Policy Research Center (EPRC).the system will help to manage information created manually and electronically and to integrate all informally centrally by using the system.

Névéol A., Shooshan S., Claveau V. (2013), indexing is a crucial step in any information retrieval system.

\section{Methods}

This is a developmental qualitative survey study aims for the assessment of RMS that is being practiced by the Local Government Units of the Province of Laguna. The descriptive research is an activity involving collection of data in order to test hypothesis of to answer questions concerning status of the subject of the study.

The main purpose of utilizing the method and describe the data and characteristics about what has been studied. Descriptive research is done to gain a better understanding of topic or situation. Hence, this type of research design was the visible method to assess the RMS that is being practiced by the province and to know the difference or similarity of practicing the RMS standards.

Using survey questionnaire, the research instrument was designed with the assessment measures which were determined. The scale of (5) Strongly Agree, (4) Moderately Agree, (3) Agree, (2) Moderately Disagree (1) Strongly Disagree was used. All the gathered data was tabulated, analyzed, and interpreted using the computed weighted mean and standard deviation.

\section{Results}

Table 1. Level of IRMS Information of Record Management Society

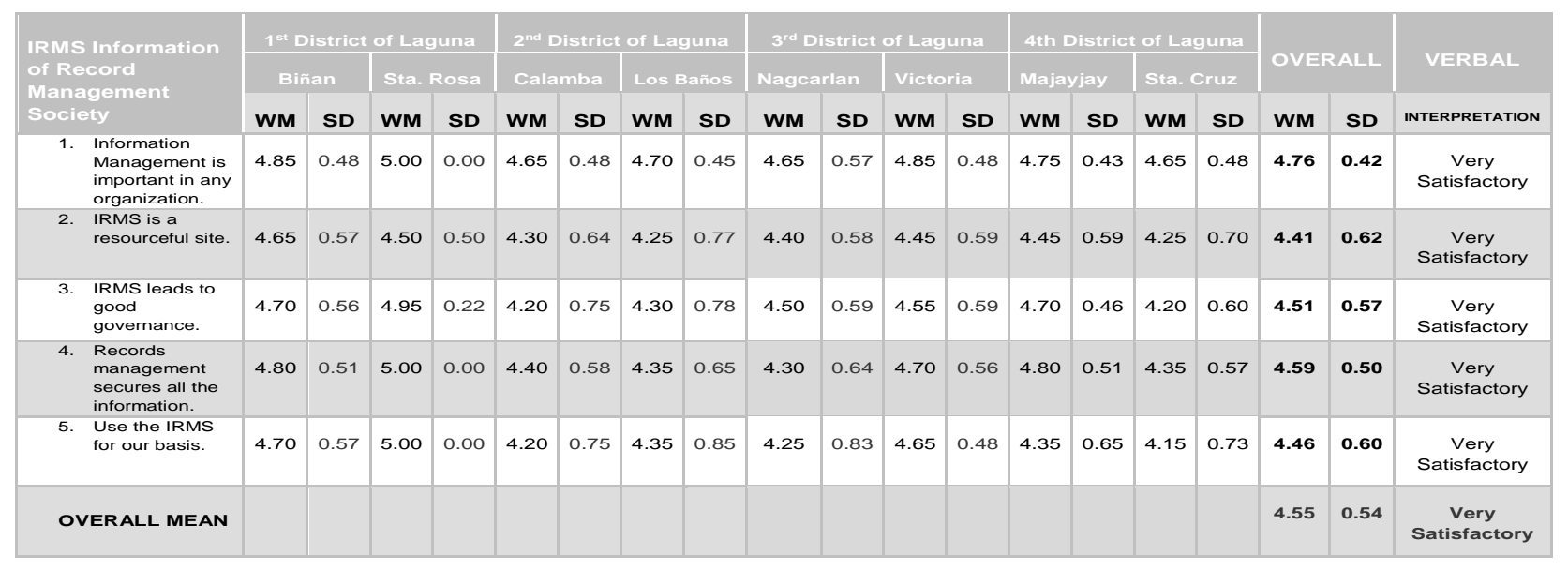

With weighted mean score of $\mathbf{4 . 5 5}$, with standard deviation of $\mathbf{0 . 5 4}$ and verbally interpreted as "Very 
Satisfactory" this means that the finding shows that the Administrative Professionals Records Management System in the four districts of Laguna as to IRMS Information of Record Management Society is highly evident.

As cited by Xiaomi A., Hongyan J. (2011) ISO 15489 has provided best practice guidelines for records management which have many implications to the world.

With the continuous compliance of the RMS standards, the Province of Laguna will have an assurance of common and standardized practices among the Administrative Professionals.

Table 2 Record Management Program.

\begin{tabular}{|c|c|c|c|c|c|c|c|c|c|c|c|c|c|c|c|c|c|c|c|}
\hline \multirow{3}{*}{$\begin{array}{l}\text { Record } \\
\text { Management } \\
\text { Program }\end{array}$} & \multicolumn{4}{|c|}{$1^{\text {st }}$ District of Laguna } & \multicolumn{4}{|c|}{$2^{\text {nd }}$ District of Laguna } & \multicolumn{4}{|c|}{$3^{\text {rd }}$ District of Laguna } & \multicolumn{4}{|c|}{$4^{\text {th }}$ District of Laguna } & \multirow{2}{*}{\multicolumn{2}{|c|}{ OVERALL }} & \multirow{3}{*}{$\begin{array}{l}\text { VERBAL } \\
\text { INTERPRETATION }\end{array}$} \\
\hline & \multicolumn{2}{|c|}{ Biñan } & \multicolumn{2}{|c|}{ Sta. Rosa } & \multicolumn{2}{|c|}{ Calamba } & \multicolumn{2}{|c|}{ Los Baños } & \multicolumn{2}{|c|}{ Nagcarlan } & \multicolumn{2}{|c|}{ Victoria } & \multicolumn{2}{|c|}{ Majayjay } & \multicolumn{2}{|c|}{ Sta. Cruz } & & & \\
\hline & WM & SD & WM & SD & WM & SD & WM & SD & WM & SD & WM & SD & WM & SD & WM & SD & WM & SD & \\
\hline $\begin{array}{l}\text { 1. We need record } \\
\text { manage system } \\
\text { such as naming } \\
\text { the file according } \\
\text { to it's purpose. }\end{array}$ & 4.80 & 0.51 & 4.95 & 0.21 & 4.45 & 0.60 & 4.50 & 0.59 & 4.40 & 0.58 & 4.75 & 0.43 & 4.40 & 0.49 & 4.50 & 0.59 & 4.59 & 0.50 & $\begin{array}{c}\text { Very } \\
\text { Satisfactory }\end{array}$ \\
\hline $\begin{array}{l}\text { 2. The } \\
\text { management use } \\
\text { spreadsheet to } \\
\text { be more } \\
\text { organized. }\end{array}$ & 4.70 & 0.56 & 4.75 & 0.43 & 4.40 & 0.66 & 4.50 & 0.59 & 4.55 & 0.50 & 4.45 & 0.67 & 4.15 & 0.48 & 4.35 & 0.57 & 4.48 & 0.56 & $\begin{array}{c}\text { Very } \\
\text { Satisfactory }\end{array}$ \\
\hline $\begin{array}{l}\text { 3. Do you share } \\
\text { records with } \\
\text { other } \\
\text { Departments. }\end{array}$ & 3.55 & 1.28 & 5.00 & 0.00 & 2.30 & 1.14 & 2.05 & 1.07 & 3.75 & 1.05 & 3.70 & 1.27 & 3.15 & 1.01 & 3.90 & 0.77 & 3.43 & 0.95 & Satisfactory \\
\hline $\begin{array}{l}\text { 4. The strategic } \\
\text { records must be } \\
\text { controversial }\end{array}$ & 3.95 & 1.20 & 4.85 & 0.36 & 4.25 & 0.94 & 4.15 & 0.96 & 4.25 & 0.83 & 4.00 & 1.22 & 3.60 & 0.92 & 3.95 & 0.67 & 4.13 & 0.89 & Satisfactory \\
\hline $\begin{array}{l}\text { 5. The overall } \\
\text { records must be } \\
\text { in alphabetical } \\
\text { order. }\end{array}$ & 4.25 & 0.83 & 4.90 & 0.30 & 4.20 & 0.93 & 4.35 & 0.85 & 4.40 & 0.80 & 4.35 & 0.79 & 4.45 & 0.59 & 4.55 & 0.59 & 4.43 & 0.71 & $\begin{array}{c}\text { Very } \\
\text { Satisfactory }\end{array}$ \\
\hline OVERALL MEAN & & & & & & & & & & & & & & & & & 4.21 & 0.72 & $\begin{array}{c}\text { Very } \\
\text { Satisfactory }\end{array}$ \\
\hline
\end{tabular}

\section{Legend:}

Scale

5

4

3

2

1

Range
$4.21-5.00$
$3.41-4.20$
$2.61-3.20$
$1.81-2.60$
$1.00-1.80$

\section{Remarks}

Strongly Agree

Agree

Neutral

Disagree

Strongly Disagree

\author{
Verbal Interpretation \\ Very Satisfactory \\ Satisfactory \\ Moderately Satisfactory \\ Less Satisfactory \\ Not Satisfactory
}

With weighted mean score of $\mathbf{4 . 2 1}$, with standard deviation of $\mathbf{0 . 7 2}$ and verbally interpreted as "Very Satisfactory" this means that the finding shows that the Administrative Professionals Records Management System in the four districts of Laguna as to Record Management Program is highly evident.

According to Mosweu T. (2019), records form the backbone of every organization as they are used as evidence of business operations. Citizens can also use them to make informed decisions and hold governments accountable.

Well-maintained and managed records or having the RMP will give security on the part of the records owners/holders that ensures the practice of confidentiality within the Province.

Accountability on the part of the Administrative Professionals for keeping, maintaining, disposing and the like, is secured. 
Table 3. Regulatory Environment

\begin{tabular}{|c|c|c|c|c|c|c|c|c|c|c|c|c|c|c|c|c|c|c|c|}
\hline \multirow{3}{*}{$\begin{array}{l}\text { Regulatory } \\
\text { Environment }\end{array}$} & \multicolumn{4}{|c|}{$1^{\text {st }}$ District of Laguna } & \multicolumn{4}{|c|}{$2^{\text {nd }}$ District of Laguna } & \multicolumn{4}{|c|}{$3^{\text {rd }}$ District of Laguna } & \multicolumn{4}{|c|}{$4^{\text {th }}$ District of Laguna } & \multirow{2}{*}{\multicolumn{2}{|c|}{ OVERALL }} & \multirow{3}{*}{$\begin{array}{l}\text { VERBAL } \\
\text { INTERPRETATION }\end{array}$} \\
\hline & \multicolumn{2}{|c|}{ Biñan } & \multicolumn{2}{|c|}{ Sta. Rosa } & \multicolumn{2}{|c|}{ Calamba } & \multicolumn{2}{|c|}{ Los Baños } & \multicolumn{2}{|c|}{ Nagcarlan } & \multicolumn{2}{|c|}{ Victoria } & \multicolumn{2}{|c|}{ Majayjay } & \multicolumn{2}{|c|}{ Sta. Cruz } & & & \\
\hline & WM & SD & WM & SD & WM & SD & WM & SD & WM & SD & WM & SD & WM & SD & WM & SD & WM & SD & \\
\hline $\begin{array}{l}\text { 1. Regulatory } \\
\text { motivates } \\
\text { decision } \\
\text { making. }\end{array}$ & 4.70 & 0.56 & 5.00 & 0.00 & 4.45 & 0.59 & 4.45 & 0.97 & 4.55 & 0.50 & 4.35 & 0.65 & 4.30 & 0.46 & 4.40 & 0.58 & 4.52 & 0.54 & $\begin{array}{c}\text { Very } \\
\text { Satisfactory }\end{array}$ \\
\hline $\begin{array}{l}\text { 2. Regulatory fit } \\
\text { should not } \\
\text { directly affect } \\
\text { the hedonic. }\end{array}$ & 4.35 & 0.79 & 4.90 & 0.30 & 4.20 & 0.98 & 4.30 & 0.95 & 4.50 & 0.67 & 4.20 & 0.74 & 3.75 & 0,43 & 4.05 & 0.59 & 4.28 & 0.72 & $\begin{array}{c}\text { Very } \\
\text { Satisfactory }\end{array}$ \\
\hline $\begin{array}{l}\text { 3. Promotes } \\
\text { feeling of } \\
\text { rightness into } \\
\text { goals. }\end{array}$ & 4.45 & 0.67 & 4.45 & 0.50 & 4.30 & 0.64 & 4.35 & 0.73 & 4.40 & 0.73 & 4.45 & 0.67 & 4.10 & 0.62 & 4.30 & 0.64 & 4.35 & 0.65 & $\begin{array}{c}\text { Very } \\
\text { Satisfactory }\end{array}$ \\
\hline $\begin{array}{l}\text { 4. Regulatory } \\
\text { intensifies } \\
\text { persuasion and } \\
\text { job satisfaction. }\end{array}$ & 4.45 & 0.66 & 4.95 & 0.22 & 4.30 & 0.71 & 4.30 & 0.71 & 4.25 & 0.70 & 4.20 & 0.93 & 4.20 & 0.60 & 4.20 & 0.68 & 4.36 & 0.65 & $\begin{array}{c}\text { Very } \\
\text { Satisfactory }\end{array}$ \\
\hline $\begin{array}{l}\text { 5. Maintain the } \\
\text { personal Value } \\
\text { and Belief's. }\end{array}$ & 4.55 & 0.59 & 4.85 & 0.36 & 4.35 & 0.57 & 4.30 & 0.64 & 4.35 & 0.65 & 4.40 & 0.58 & 4.30 & 0.46 & 4.35 & 0.57 & 4.43 & 0.55 & $\begin{array}{c}\text { Very } \\
\text { Satisfactory }\end{array}$ \\
\hline OVERALL MEAN & & & & & & & & & & & & & & & & & 4.39 & 0.62 & $\begin{array}{c}\text { Very } \\
\text { Satisfactory }\end{array}$ \\
\hline
\end{tabular}

Legend:

$\begin{array}{lll}\text { Scale } & \text { Range } & \text { Remarks } \\ 5 & 4.21-5.00 & \text { Strongly Agree } \\ 4 & 3.41-4.20 & \text { Agree } \\ 3 & 2.61-3.20 & \text { Neutral } \\ 2 & 1.81-2.60 & \text { Disagree } \\ 1 & 1.00-1.80 & \text { Strongly Disagree }\end{array}$

Verbal Interpretation
Very Satisfactory
Satisfactory
Moderately Satisfactory
Less Satisfactory
Not Satisfactory

With weighted mean score of $\mathbf{4 . 3 9}$, with standard deviation of $\mathbf{0 . 6 2}$ and verbally interpreted as "Very Satisfactory" this means that the finding shows that the Administrative Professionals Records Management System in the four districts of Laguna as to Regulatory Environment is highly evident.

Moreover according to research Hughes C. (2016), since the launch of ISO-15489 there have been more opportunities available to records managers to help them align themselves to the strategic direction of their organization, raise their profile and increase awareness of their role.

Administrative Professionals, as records managers, can easily be adaptive of the RMS compliance when there is a standardized and harmonized of a regulatory environment.

Table 4. Functionality and components of record system

\begin{tabular}{|c|c|c|c|c|c|c|c|c|c|c|c|c|c|c|c|c|c|c|c|}
\hline \multirow{3}{*}{$\begin{array}{l}\text { Functionality and } \\
\text { components of } \\
\text { record system }\end{array}$} & \multicolumn{4}{|c|}{$1^{\text {st }}$ District of Laguna } & \multicolumn{4}{|c|}{$2^{\text {nd }}$ District of Laguna } & \multicolumn{4}{|c|}{$3^{\text {rd }}$ District of Laguna } & \multicolumn{4}{|c|}{$4^{\text {th }}$ District of Laguna } & \multirow{2}{*}{\multicolumn{2}{|c|}{ OVERALL }} & \multirow{3}{*}{$\begin{array}{l}\text { VERIBAL } \\
\text { INTERPRETATION }\end{array}$} \\
\hline & \multicolumn{2}{|c|}{ Biñan } & \multicolumn{2}{|c|}{ Sta. Rosa } & \multicolumn{2}{|c|}{ Calamba } & \multicolumn{2}{|c|}{ Los Baños } & \multicolumn{2}{|c|}{ Nagcarlan } & \multicolumn{2}{|c|}{ Victoria } & \multicolumn{2}{|c|}{ Majayjay } & \multicolumn{2}{|c|}{ Sta. Cruz } & & & \\
\hline & WM & SD & WM & SD & WM & SD & WM & SD & WM & SD & WM & SD & WM & SD & WM & SD & WM & SD & \\
\hline $\begin{array}{l}\text { 1. Creation of } \\
\text { records in context. }\end{array}$ & 4.50 & 0.59 & 4.95 & 0.22 & 4.25 & 0.62 & 4.40 & 0.58 & 4.25 & 0.62 & 4.60 & 0.58 & 4.20 & 0.60 & 4.50 & 0.59 & 4.46 & 0.55 & $\begin{array}{l}\text { Very } \\
\text { Satisfactory }\end{array}$ \\
\hline $\begin{array}{l}\text { 2. Management and } \\
\text { Maintenance of } \\
\text { records }\end{array}$ & 4.60 & 0.73 & 4.90 & 0.30 & 4.40 & 0.66 & 4.50 & 0.50 & 4.50 & 0.50 & 4.65 & 0.48 & 4.35 & 0.48 & 4.45 & 0.59 & 4.54 & 0.53 & $\begin{array}{l}\text { Very } \\
\text { Satisfactory }\end{array}$ \\
\hline $\begin{array}{l}\text { 3. Retention and } \\
\text { Disposition of } \\
\text { records. }\end{array}$ & 4.65 & 0.65 & 4.95 & 0.22 & 4.20 & 0.60 & 4.35 & 0.48 & 4.30 & 0.64 & 4.35 & 0.73 & 4.25 & 0.43 & 4.40 & 0.58 & 4.43 & 0.54 & $\begin{array}{l}\text { Very } \\
\text { Satisfactory }\end{array}$ \\
\hline $\begin{array}{l}\text { 4. The relationship } \\
\text { between work } \\
\text { processes and } \\
\text { their business } \\
\text { context. }\end{array}$ & 4.45 & 0.59 & 4.45 & 0.50 & 4.25 & 0.70 & 4.10 & 0.77 & 4.35 & 0.72 & 4.20 & 0.68 & 4.20 & 0.51 & 4.30 & 0.46 & 4.29 & 0.62 & $\begin{array}{l}\text { Very } \\
\text { Satisfactory }\end{array}$ \\
\hline $\begin{array}{l}\text { The sequential } \\
\text { interdependencies } \\
\text { between discrete } \\
\text { work processes or } \\
\text { single } \\
\text { transactions. }\end{array}$ & 4.45 & 0.67 & 4.90 & 0.30 & 4.05 & 0.59 & 4.00 & 0.45 & 4.40 & 0.49 & 4.30 & 0.64 & 4.10 & 0.44 & 4.25 & 0.54 & 4.31 & 0.52 & $\begin{array}{l}\text { Very } \\
\text { Satisfactory }\end{array}$ \\
\hline OVERALL MEAN & & & & & & & & & & & & & & & & & 4.41 & 0.55 & $\begin{array}{c}\text { Very } \\
\text { Satisfactory }\end{array}$ \\
\hline
\end{tabular}


With weighted mean score of 4.41, with standard deviation of $\mathbf{0 . 5 5}$ and verbally interpreted as "Very Satisfactory" this means that the finding shows that the Administrative Professionals Records Management System in the four districts of Laguna as to Functionality and Components of Records System is highly evident.

As per Freda A., (2014), in order to define records management, the concept of "record" needs to be fully explored. A record is defined either in terms of the physical tangible format in which it appears, or in terms of the information it contains.

The Administrative Professionals of the Provincial Government of Laguna have already learned the functionality and components of each record that they are managing in the duration of their duties thus, they know the very purpose of each record and its usage within and outside their jurisdiction.

Table 5. Record Management Process and Control

\begin{tabular}{|c|c|c|c|c|c|c|c|c|c|c|c|c|c|c|c|c|c|c|c|}
\hline \multirow{3}{*}{$\begin{array}{l}\text { Record Management } \\
\text { Process and Control }\end{array}$} & \multicolumn{4}{|c|}{$1^{\text {st }}$ District of Laguna } & \multicolumn{4}{|c|}{$2^{\text {nd }}$ District of Laguna } & \multicolumn{4}{|c|}{$3^{\text {rd }}$ District of Laguna } & \multicolumn{4}{|c|}{$4^{\text {th }}$ District of Laguna } & \multirow{2}{*}{\multicolumn{2}{|c|}{ OVERALL }} & \multirow{3}{*}{$\begin{array}{c}\text { VERBAL } \\
\text { INTERPRETATION }\end{array}$} \\
\hline & \multicolumn{2}{|c|}{ Biñan } & \multicolumn{2}{|c|}{ Sta. Rosa } & \multicolumn{2}{|c|}{ Calamba } & \multicolumn{2}{|c|}{ Los Baños } & \multicolumn{2}{|c|}{ Nagcarlan } & \multicolumn{2}{|c|}{ Victoria } & \multicolumn{2}{|c|}{ Majayjay } & \multicolumn{2}{|c|}{ Sta. Cruz } & & & \\
\hline & WM & SD & WM & SD & WM & SD & WM & SD & WM & SD & WM & SD & WM & SD & WM & SD & WM & SD & \\
\hline $\begin{array}{l}\text { 1. Records } \\
\text { Retention } \\
\text { Schedule. }\end{array}$ & 4.45 & 0.67 & 4.85 & 0.36 & 4.30 & 0.46 & 4.25 & 0.53 & 4.70 & 0.46 & 4.50 & 0.59 & 4.25 & 0.43 & 4.40 & 0.49 & 4.46 & 0.50 & $\begin{array}{c}\text { Very } \\
\text { Satisfactory }\end{array}$ \\
\hline $\begin{array}{l}\text { 2. Policies and } \\
\text { Procedures. }\end{array}$ & 4.80 & 0,51 & 4.85 & 0.36 & 4.30 & 0.56 & 4.35 & 0.57 & 4.55 & 0.50 & 4.55 & 0.50 & 4.45 & 0.50 & 4.35 & 0.57 & 4.53 & 0.51 & $\begin{array}{c}\text { Very } \\
\text { Satisfactory }\end{array}$ \\
\hline $\begin{array}{l}\text { 3. Accessibility, } \\
\text { Indexing, and } \\
\text { Storage }\end{array}$ & 4.55 & 0.74 & 4.90 & 0.30 & 4.20 & 0.68 & 4.25 & 0.62 & 4.50 & 0.50 & 4.60 & 0.49 & 4.30 & 0.56 & 4.40 & 0.49 & 4.46 & 0.55 & $\begin{array}{c}\text { Very } \\
\text { Satisfactory }\end{array}$ \\
\hline $\begin{array}{l}\text { 4. Compliance } \\
\text { Auditing }\end{array}$ & 4.50 & 0.74 & 4.80 & 0.40 & 4.25 & 0.62 & 4.40 & 0.66 & 4.50 & 0.59 & 4.55 & 0.50 & 4.25 & 0.43 & 4.25 & 0.62 & 4.44 & 0.57 & $\begin{array}{c}\text { Very } \\
\text { Satisfactory }\end{array}$ \\
\hline $\begin{array}{l}\text { 5. Disposal of } \\
\text { Obsolete } \\
\text { Records }\end{array}$ & 4.45 & 1.02 & 4.95 & 0.22 & 4.20 & 0.68 & 4.20 & 0.75 & 4.35 & 0.57 & 4.35 & 0.79 & 4.15 & 0.57 & 4.15 & 0.85 & 4.35 & 0.68 & $\begin{array}{c}\text { Very } \\
\text { Satisfactory }\end{array}$ \\
\hline OVERALL MEAN & & & & & & & & & & & & & & & & & 4.45 & 0.56 & $\begin{array}{c}\text { Very } \\
\text { Satisfactory }\end{array}$ \\
\hline
\end{tabular}

$\begin{array}{ll}\text { Legend: } & \\ \text { Scale } & \text { Range } \\ 5 & 4.21-5.00 \\ 4 & 3.41-4.20 \\ 3 & 2.61-3.20 \\ 2 & 1.81-2.60 \\ 1 & 1.00-1.80\end{array}$

Remarks
Strongly Agree
Agree
Neutral
Disagree
Strongly Disagree

\author{
Verbal Interpretation \\ Very Satisfactory \\ Satisfactory \\ Moderately Satisfactory \\ Less Satisfactory \\ Not Satisfactory
}

With weighted mean score of 4.46, with standard deviation of $\mathbf{0 . 5 6}$ and verbally interpreted as "Very Satisfactory" this means that the finding shows that the Administrative Professionals Records Management System in the four districts of Laguna as to Record Management Process and Control is highly evident.

Lewellen M. J. (2015), an authentic record is one that can be proven to be what it purports to be, to have been created or sent by the person purported to have created or sent it, and to have been created or sent at the purported time (ISO 15489.1, 2002, p. 7).

The Administrative Professionals have very satisfactory practices in the management, processing and control of records. This can be shown from the time of creation, retention and disposal policies. 
Table 6. ARMA Association of Records Managers \& Administrators

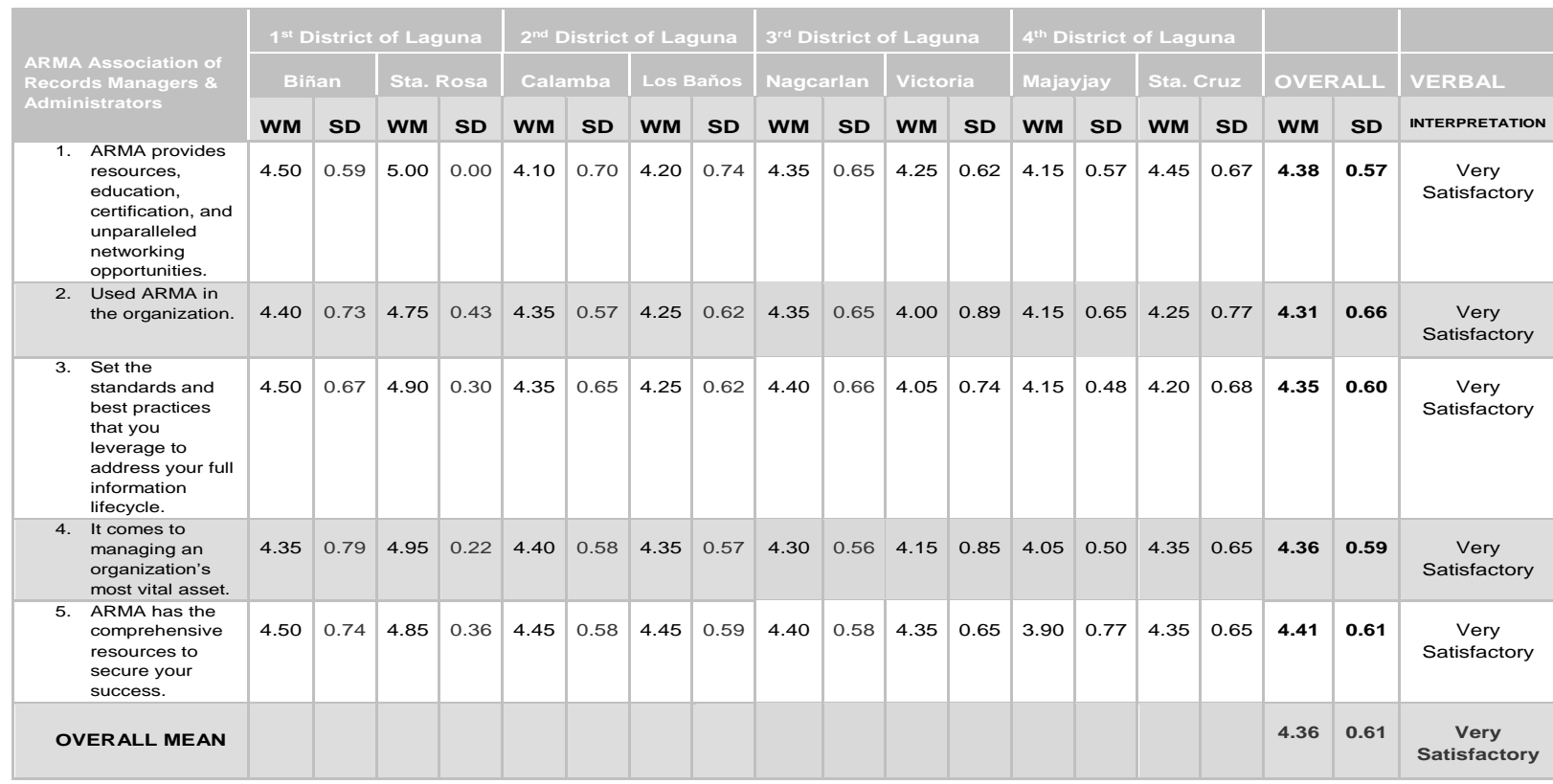

$\begin{array}{llll}\text { Legend: } & & & \\ \text { Scale } & \text { Range } & \text { Remarks } & \text { Verbal Interpretation } \\ 5 & 4.21-5.00 & \text { Strongly Agree } & \text { Very Satisfactory } \\ 4 & 3.41-4.20 & \text { Agree } & \text { Satisfactory } \\ 3 & 2.61-3.20 & \text { Neutral } & \text { Moderately Satisfactory } \\ 2 & 1.81-2.60 & \text { Disagree } & \text { Less Satisfactory } \\ 1 & 1.00-1.80 & \text { Strongly Disagree } & \text { Not Satisfactory }\end{array}$

With weighted mean score of $\mathbf{4 . 3 6}$, with standard deviation of $\mathbf{0 . 6 1}$ and verbally interpreted as "Very Satisfactory" this means that the finding shows that the Administrative Professionals Records Management System in the four districts of Laguna as to ARMA Association of Records Managers \& Administrators is highly evident.

According to McCue C. (2015), most departments maintain large records management systems (RMS) that contain crime incident data. In most cases, however, these "databases" were not necessarily designed to be analyzed. Rather, these databases were created and are used for case management and general crime counting. As a result, these databases frequently have standard or "canned" queries that facilitate gathering frequently used information or reports; however, these often have limited utility for crime analysis.

With the aforesaid set of standards for the Administrative Professionals in the Provincial Government of Laguna are following, the credibility of records is built. 
Table 7. Filing Methods

\begin{tabular}{|c|c|c|c|c|c|c|c|c|c|c|c|c|c|c|c|c|c|c|c|}
\hline \multirow{3}{*}{ Filing Methods } & \multicolumn{4}{|c|}{$1^{\text {st }}$ District of Laguna } & \multicolumn{4}{|c|}{$2^{\text {nd }}$ District of Laguna } & \multicolumn{4}{|c|}{$3^{\text {rd }}$ District of Laguna } & \multicolumn{4}{|c|}{$4^{\text {th }}$ District of Laguna } & \multirow{2}{*}{\multicolumn{2}{|c|}{ OVERALL }} & \multirow{3}{*}{$\begin{array}{l}\text { VERBAI } \\
\text { INTERPRETAT }\end{array}$} \\
\hline & \multicolumn{2}{|c|}{ Biñan } & \multicolumn{2}{|c|}{ Sta. Rosa } & \multicolumn{2}{|c|}{ Calamba } & \multicolumn{2}{|c|}{ Los Baños } & \multicolumn{2}{|c|}{ Nagcarlan } & \multicolumn{2}{|c|}{ Victoria } & \multicolumn{2}{|c|}{ Majayjay } & \multicolumn{2}{|c|}{ Sta. Cruz } & & & \\
\hline & wM & SD & WM & SD & wM & SD & WM & SD & wM & SD & WM & SD & wM & SD & wm & SD & wm & SD & \\
\hline $\begin{array}{l}\text { 1. Filing by } \\
\text { Subject/Category. }\end{array}$ & 4.75 & 0.53 & 5.00 & 0.00 & 4.55 & 0.59 & 4.60 & 0.58 & 4.60 & 0.58 & 4.65 & 0.57 & 4.50 & 0.59 & 4.50 & 0.50 & 4.64 & 0.49 & $\begin{array}{c}\text { Very } \\
\text { Satisfacto }\end{array}$ \\
\hline $\begin{array}{l}\text { 2. Filing in } \\
\text { Alphabetical } \\
\text { order. }\end{array}$ & 4.20 & 1.03 & 4.95 & 0.30 & 4.40 & 0.66 & 4.40 & 0.66 & 4.70 & 0.46 & 4.60 & 0.58 & 4.45 & 0.60 & 4.50 & 0.67 & 4.53 & 0.62 & $\begin{array}{c}\text { Very } \\
\text { Satisfacto }\end{array}$ \\
\hline $\begin{array}{l}\text { 3. Filing by } \\
\text { Numbers/Numeric } \\
\text { al order. }\end{array}$ & 4.30 & 0.78 & 4.85 & 0.22 & 4.40 & 0.73 & 4.40 & 0.66 & 4.70 & 0.46 & 4.40 & 0.66 & 4.10 & 0.70 & 4.45 & 0.59 & 4.45 & 0.60 & $\begin{array}{c}\text { Very } \\
\text { Satisfacto }\end{array}$ \\
\hline $\begin{array}{l}\text { 4. Filing by } \\
\text { Places/Geographi } \\
\text { cal order. }\end{array}$ & 4.10 & 0.99 & 4.85 & 0.36 & 4.45 & 0.67 & 4.40 & 0.66 & 4.55 & 0.60 & 4.50 & 0.59 & 4.05 & 0.67 & 4.30 & 0.56 & 4.40 & 0.64 & $\begin{array}{c}\text { Very } \\
\text { Satisfacto }\end{array}$ \\
\hline $\begin{array}{l}\text { 5. Filing by } \\
\text { Dates/Chronologi } \\
\text { cal order. }\end{array}$ & 4.55 & 0.67 & 4.91 & 0.36 & 4.55 & 0.74 & 4.80 & 0.40 & 4.55 & 0.60 & 4.40 & 0.80 & 4.30 & 0.64 & 4.40 & 0.58 & 4.56 & 0.60 & $\begin{array}{c}\text { Very } \\
\text { Satisfacto }\end{array}$ \\
\hline OVERALL MEAN & & & & & & & & & & & & & & & & & 4.52 & 0.59 & $\begin{array}{c}\text { Very } \\
\text { Satisfacto }\end{array}$ \\
\hline
\end{tabular}

$\begin{array}{llll}\text { Legend: } & & & \\ \text { Scale } & \text { Range } & \text { Remarks } & \text { Verbal Interpretation } \\ 5 & 4.21-5.00 & \text { Strongly Agree } & \text { Very Satisfactory } \\ 4 & 3.41-4.20 & \text { Agree } & \text { Satisfactory } \\ 3 & 2.61-3.20 & \text { Neutral } & \text { Moderately Satisfactory } \\ 2 & 1.81-2.60 & \text { Disagree } & \text { Less Satisfactory } \\ 1 & 1.00-1.80 & \text { Strongly Disagree } & \text { Not Satisfactory }\end{array}$

With weighted mean score of $\mathbf{4 . 6 2}$, with standard deviation of $\mathbf{0 . 5 9}$ and verbally interpreted as "Very Satisfactory" this means that the finding shows that the Administrative Professionals Records Management System in the four districts of Laguna as to Filing Methods is highly evident.

According to Geofrey K. (2013), identified a need to recommend a system for managing records at the Economic Policy Research Center (EPRC).the system will help to manage information created manually and electronically and to integrate all informally centrally by using the system.

\section{Table 8. Filing Procedures}

\begin{tabular}{|c|c|c|c|c|c|c|c|c|c|c|c|c|c|c|c|c|c|c|c|}
\hline \multirow{3}{*}{ Indexing Rules } & \multicolumn{4}{|c|}{$1^{\text {st }}$ District of Laguna } & \multicolumn{4}{|c|}{$2^{\text {nd }}$ District of Laguna } & \multicolumn{4}{|c|}{$3^{\text {rd }}$ District of Laguna } & \multicolumn{4}{|c|}{$4^{\text {th }}$ District of Laguna } & \multirow{2}{*}{\multicolumn{2}{|c|}{ OVERALL }} & \multirow{3}{*}{$\begin{array}{l}\text { VERBAL. } \\
\text { INTERPRETATION }\end{array}$} \\
\hline & \multicolumn{2}{|c|}{ Biñan } & \multicolumn{2}{|c|}{ Sta. Rosa } & \multicolumn{2}{|c|}{ Calamba } & \multicolumn{2}{|c|}{ Los Baños } & \multicolumn{2}{|c|}{ Nagcarlan } & \multicolumn{2}{|c|}{ Victoria } & \multicolumn{2}{|c|}{ Majayjay } & \multicolumn{2}{|c|}{ Sta. Cruz } & & & \\
\hline & WM & SD & WM & SD & WM & SD & WM & SD & WM & SD & WM & SD & WM & SD & WM & SD & WM & SD & \\
\hline $\begin{array}{l}\text { 1. Personal } \\
\text { Names with } \\
\text { Prefixes }\end{array}$ & 4.55 & 0.73 & 5.00 & 0.00 & 4.35 & 0.65 & 4.25 & 0.62 & 4.50 & 0.50 & 4.55 & 0.50 & 4.10 & 0.62 & 4.50 & 0.50 & 4.48 & 0.52 & $\begin{array}{c}\text { Very } \\
\text { Satisfactory }\end{array}$ \\
\hline $\begin{array}{l}\text { 2. Hyphenated } \\
\text { Personal } \\
\text { Names }\end{array}$ & 4.40 & 0.80 & 4.75 & 0.43 & 4.35 & 0.79 & 4.30 & 0.84 & 4.70 & 0.46 & 4.35 & 0.48 & 4.25 & 0.62 & 4.40 & 0.49 & 4.44 & 0.61 & $\begin{array}{c}\text { Very } \\
\text { Satisfactory }\end{array}$ \\
\hline $\begin{array}{l}\text { 3. Personal } \\
\text { Names with } \\
\text { Titles and } \\
\text { Suffixes. }\end{array}$ & 4.40 & 0.66 & 4.75 & 0.43 & 4.45 & 0.67 & 4.35 & 0.65 & 4.60 & 0.49 & 4.50 & 0.59 & 4.40 & 0.66 & 4.30 & 0.46 & 4.47 & 0.58 & $\begin{array}{c}\text { Very } \\
\text { Satisfactory }\end{array}$ \\
\hline $\begin{array}{l}\text { 4. Names of } \\
\text { Businesses } \\
\text { and } \\
\text { Organizations. }\end{array}$ & 4.35 & 0.72 & 4.90 & 0.30 & 4.35 & 0.57 & 4.25 & 0.62 & 4.55 & 0.50 & 4.55 & 0.50 & 4.15 & 0.65 & 4.35 & 0.48 & 4.43 & 0.54 & $\begin{array}{c}\text { Very } \\
\text { Satisfactory }\end{array}$ \\
\hline $\begin{array}{l}\text { 5. Government } \\
\text { Names / State } \\
\text { and Local } \\
\text { Government. }\end{array}$ & 4.45 & 0.67 & 4.80 & 0.40 & 4.50 & 0.50 & 4.25 & 0.62 & 4.50 & 0.50 & 4.55 & 0.50 & 4.25 & 0.62 & 4.40 & 0.58 & 4.46 & 0.55 & $\begin{array}{c}\text { Very } \\
\text { Satisfactory }\end{array}$ \\
\hline OVERALL MEAN & & & & & & & & & & & & & & & & & 4.46 & 0.56 & $\begin{array}{c}\text { Very } \\
\text { Satisfactory }\end{array}$ \\
\hline
\end{tabular}


With weighted mean score of 4.51, with standard deviation of $\mathbf{0 . 5 4}$ and verbally interpreted as "Very Satisfactory" this means that this means that the finding shows that the Administrative Professionals Records Management System in the four districts of Laguna as to Filing Procedures is highly evident.

Cited by Xiaomi A., Hongyan J. (2011), ISO 15489 has provided best practice guidelines for records management which have many implications to the world.

With the standardized RMS, the records that are being kept, maintained, used, issued to the stakeholders by the administrative professionals of the province has a positive impact on the society it serves.

Table 9. Indexing Rules

\begin{tabular}{|c|c|c|c|c|c|c|c|c|c|c|c|c|c|c|c|c|c|c|c|}
\hline \multirow{3}{*}{ Filing Procedures } & \multicolumn{4}{|c|}{$1^{\text {st }}$ District of Laguna } & \multicolumn{4}{|c|}{$2^{\text {nd }}$ District of Laguna } & \multicolumn{4}{|c|}{$3^{\text {rd }}$ District of Laguna } & \multicolumn{4}{|c|}{$4^{\text {th }}$ District of Laguna } & \multirow{2}{*}{\multicolumn{2}{|c|}{ OVERALL }} & \multirow{3}{*}{ VERBAL } \\
\hline & \multicolumn{2}{|c|}{ Biñan } & \multicolumn{2}{|c|}{ Sta. Rosa } & \multicolumn{2}{|c|}{ Calamba } & \multicolumn{2}{|c|}{ Los Baños } & \multicolumn{2}{|c|}{ Nagcarlan } & \multicolumn{2}{|c|}{ Victoria } & \multicolumn{2}{|c|}{ Majayjay } & \multicolumn{2}{|c|}{ Sta. Cruz } & & & \\
\hline & WM & SD & WM & SD & WM & SD & WM & SD & wM & SD & WM & SD & WM & SD & WM & SD & WM & SD & \\
\hline $\begin{array}{l}\text { 1. Can easily } \\
\text { retrieved files }\end{array}$ & 4.60 & 0.66 & 5.00 & 0.00 & 4.40 & 0.66 & 4.35 & 0.73 & 4.50 & 0.50 & 4.90 & 0.30 & 4.40 & 0.49 & 4.55 & 0.59 & 4.59 & 0.49 & $\begin{array}{c}\text { Very } \\
\text { Satisfactory }\end{array}$ \\
\hline $\begin{array}{l}\text { 2. Adequate in } \\
\text { transfer files }\end{array}$ & 4.65 & 0.57 & 4.80 & 0.40 & 4.10 & 0.62 & 4.00 & 0.71 & 4.45 & 0.49 & 4.55 & 0.74 & 4.30 & 0.46 & 4.45 & 0.59 & 4.41 & 0.57 & $\begin{array}{c}\text { Very } \\
\text { Satisfactory }\end{array}$ \\
\hline $\begin{array}{l}\text { 3. Sorting and } \\
\text { Filing filed in } \\
\text { the correct } \\
\text { classification. }\end{array}$ & 4.65 & 0.57 & 5.00 & 0.00 & 4.45 & 0.86 & 4.35 & 0.73 & 4.50 & 0.40 & 4.50 & 0.67 & 4.35 & 0.57 & 4.45 & 0.67 & 4.53 & 0.56 & $\begin{array}{c}\text { Very } \\
\text { Satisfactory }\end{array}$ \\
\hline $\begin{array}{l}\text { 4. Easily order to } \\
\text { file documents. }\end{array}$ & 4.65 & 0.57 & 4.80 & 0.40 & 4.45 & 0.58 & 4.40 & 0.66 & 4.35 & 0.57 & 4.80 & 0.40 & 4.35 & 0.73 & 4.55 & 0.50 & 4.54 & 0.55 & $\begin{array}{c}\text { Very } \\
\text { Satisfactory }\end{array}$ \\
\hline $\begin{array}{l}\text { 5. Effortlessly } \\
\text { follow up slip. }\end{array}$ & 4.35 & 0.72 & 5.00 & 0.00 & 4.35 & 0.65 & 4.45 & 0.67 & 4.40 & 0.58 & 4.65 & 0.48 & 4.10 & 0.77 & 4.55 & 0.50 & 4.48 & 0.55 & $\begin{array}{c}\text { Very } \\
\text { Satisfactory }\end{array}$ \\
\hline OVERALL MEAN & & & & & & & & & & & & & & & & & 4.51 & 0.54 & $\begin{array}{c}\text { Very } \\
\text { Satisfactory }\end{array}$ \\
\hline
\end{tabular}

Legend:

Scale

5

4

3

2

1

Range
$4.21-5.00$
$3.41-4.20$
$2.61-3.20$
$1.81-2.60$
$1.00-1.80$

\section{Remarks}

Strongly Agree

Agree

Neutral

Disagree

Strongly Disagree

\author{
Verbal Interpretation \\ Very Satisfactory \\ Satisfactory \\ Moderately Satisfactory \\ Less Satisfactory \\ Not Satisfactory
}

With weighted mean score of $\mathbf{4 . 4 6}$, with standard deviation of $\mathbf{0 . 5 6}$ and verbally interpreted as "Very Satisfactory" this means that the finding shows that the Administrative Professionals Records Management System in the four districts of Laguna as to Indexing Rules is highly evident.

Névéol A., Shooshan S., Claveau V. (2013), indexing is a crucial step in any information retrieval system.

Proper indexing practice of the administrative professionals in the province has immense into a smooth workflow. 
Table 10. Significant difference in the respondent's perception on the level of administrative professional practices on Records Management System.

\begin{tabular}{|c|c|c|c|c|}
\hline \multirow{2}{*}{ SANTA ROSA } & \multirow{2}{*}{$\begin{array}{l}\text { Respondents } \\
\text { Perception }\end{array}$} & t-value & p-value & Analysis \\
\hline & & T STAT & T CRIT & FINDINGS \\
\hline \multirow{7}{*}{$\begin{array}{l}\text { Administrative Professional } \\
\text { Practices on Records } \\
\text { Management System }\end{array}$} & BINAN & -3.0789 & -2.0244 & SIGNIFICANT \\
\hline & CALAMBA & 9.8073 & 2.0244 & SIGNIFICANT \\
\hline & LOS BANOS & 8.4080 & 2.0244 & SIGNIFICANT \\
\hline & NAGCARLAN & 6.1720 & 2.0244 & SIGNIFICANT \\
\hline & VICTORIA & 5.1900 & 2.0244 & SIGNIFICANT \\
\hline & MAJAYJAY & 7.6462 & 2.0244 & SIGNIFICANT \\
\hline & STA CRUZ & 6.1685 & 2.0244 & SIGNIFICANT \\
\hline
\end{tabular}

Table 10 shows that there is a significant difference in the respondent's perception on the level of administrative professional practices on records management system.

Municipalities vary in the respondents' perception on Records Management System as compared to the standard. This means that the administrative professionals in the four (4) districts in Laguna are differed in their practices on Records Management for having been different in the perception on the mentioned RMS Standards.

\section{Conclusions}

1. Of the 160 administrative professionals in the Provincial Government of Laguna, the nine (9) given measures on Records Management System as to; IRMS, Regulatory Environment, Functionality and components of record system, Record management processes and control, ARMA, Filing Methods, Filing Procedures, Indexing Rules, is "Very Satisfactory."

2. This can be inferred that the Administrative professionals fully aware of the standards and are performing best practices in RMS.

3. On the other hand, Municipalities in the four (4) districts of the Province of Laguna vary in the administrative professional's perception on the standards of RMS. All municipalities highly agree on the given set of RMS parameters, but do not have common perception to the same.

\section{Recommendations}

1. The Local Government Units of the Provincial Government of Laguna may consider organizing a Record Management System Program to unify the practices of all Administrative Professionals.

2. The researcher further recommends the Development of Standardized Electronic Records Management System for Local Government Units (ERMS-LGUs) to modified and standardized the RMS system of the Provincial Government of Laguna, and to be able to serve the province through an electronic system that would be best practices mostly during the time of new normal.

3. This study can be recommended to researchers as reference in doing related studies in the future. 


\section{References}

1. Adu Freda (2014) ASSESSMENT OF RECORDS MANAGEMENT PRACTICES AMONG THE ADMINISTRATIVE STAFF OF UNIVERSITY OF EDUCATION : http://ir.knust.edu.gh/bitstream/123456789/7540/1/Adu\%20Freda

2. Development Programme for Office Professionals (Secretary/PA) Based on SAQA's Unit Standard 110021, NQF Level 4, 6 Credits

3. Geofrey K (2013) Designing An Effective Records Management System A Case Study Of The Economic Policy Research Center Eprc Uganda:

4. https://www.researchgate.net/publication/337679311_DESIGNING_AN_EFFECTIVE_RECORDS_MA NAGEMENT_SYSTEM_A_CASE_STUDY_OF_THE_ECONOMIC_POLICY_RESEARCH_CENTER _EPRC_UGANDA

5. Hughes C. (2016) Opportunities for records managers working in the private sector: https://www.emerald.com/insight/content/doi/10.1108/09565690310509264/full/html.

6. ISO 15489 (1:2001 Information and Documentation - Records Management)

7. Lewellen (2015) US National Archives and Records Administration Guidance on Managing Web Records: What Are the Characteristics of Trustworthy Records? http://researcharchive.vuw.ac.nz/xmlui/bitstream/handle/10063/4144/thesis.pdf?sequence=2

8. Lewellen M. J. (2015) The Impact of the Perceived Value of Records on the Use of Electronic Recordkeeping Systems. https://core.ac.uk/download/pdf/41339424.pdf

9. McCue C. (2015) Data Mining and Predictive Analysis (Second Edition) https://www.sciencedirect.com/topics/computer-science/record-management-system

10. Mosweu T. (2019) The Role of Records Management in the Attainment of Sustainable Development Goals: http://www.academia.edu/Documents/in/Records_Management.

11. Mutula, S.M. (2015),Electronic records management research in ESARBICA: a bibliometric study: https://www.emerald.com/insight/content/doi/10.1108/RMJ-12-2016-0045/full/html

12. Névéol A., Shooshan S., Claveau V. (2013) Automatic inference of indexing rules for MEDLINE https://link.springer.com/article/10.1186/1471-2105-9-S11-S11

13. Procter J. (2013) International records management standards The challenges of achieving consensus https://www.researchgate.net/publication/260752929_International_records_management_standards_The_ challenges_of_achieving_consensus 